\title{
Within What Distance Does "Greenness" Best Predict Physical Health? A Systematic Review of Articles with GIS Buffer Analyses across the Lifespan
}

\author{
Matthew Browning 1,2,* (D) and Kangjae Lee ${ }^{2}$ \\ 1 Department of Recreation, Sport and Tourism, University of Illinois at Urbana-Champaign, \\ Champaign, IL 61820, USA \\ 2 Illinois Informatics Institute, University of Illinois at Urbana-Champaign, Champaign, IL 61802, USA; \\ klee171@illinois.edu \\ * Correspondence: brownin@illinois.edu; Tel.: +1-217-300-3496
}

Academic Editor: Paul B. Tchounwou

Received: 31 May 2017; Accepted: 21 June 2017; Published: 23 June 2017

\begin{abstract}
Is the amount of "greenness" within a 250-m, 500-m, 1000-m or a 2000-m buffer surrounding a person's home a good predictor of their physical health? The evidence is inconclusive. We reviewed Web of Science articles that used geographic information system buffer analyses to identify trends between physical health, greenness, and distance within which greenness is measured. Our inclusion criteria were: (1) use of buffers to estimate residential greenness; (2) statistical analyses that calculated significance of the greenness-physical health relationship; and (3) peer-reviewed articles published in English between 2007 and 2017. To capture multiple findings from a single article, we selected our unit of inquiry as the analysis, not the article. Our final sample included 260 analyses in 47 articles. All aspects of the review were in accordance with PRISMA guidelines. Analyses were independently judged as more, less, or least likely to be biased based on the inclusion of objective health measures and income/education controls. We found evidence that larger buffer sizes, up to $2000 \mathrm{~m}$, better predicted physical health than smaller ones. We recommend that future analyses use nested rather than overlapping buffers to evaluate to what extent greenness not immediately around a person's home (i.e., within 1000-2000 m) predicts physical health.
\end{abstract}

Keywords: systematic review; greenness; Geographic Information System (GIS); physical health; buffers; green space; park; health outcomes; Normalized Difference Vegetation Index (NDVI)

\section{Introduction}

As a result of rapid urbanization, a growing disconnect from nature, and rising rates of disease and illness, many groups are increasingly interested in the effects of greenspaces on physical health. Greenspaces provide daily opportunities for physical exercise and stress relief [1]. The distance within which greenspaces provide these opportunities to any meaningful degree, however, is not well understood. Is there a stronger correlation between health and greenspaces within $250 \mathrm{~m}$ of someone's home, than those within $1000 \mathrm{~m}$ of someone's home? The empirical evidence needed to answer such questions is lacking.

Our current understanding of the distance within which greenness matters is based largely on expert opinion. In the United States, some practitioners suggest that having greenspace within a five-minute walk (approximately 0.2 miles or $0.32 \mathrm{~km}$ ) is most important for physical health, while others assert that a 0.50 - or 0.75 -mile $(0.80$ or $1.20 \mathrm{~km})$ range is more accurate [2]. A better understanding of the maximum distance to consider when analyzing greenspace would help urban planners and 
public health officials better evaluate how to design minimum standards for greenspaces near members of their communities.

Geographic information system (GIS) software packages (i.e., ArcGIS, ESRI Inc., Redlands, CA, USA) provide powerful tools to provide empirical evidence on how different distances in which greenness is measured impact physical health. A multitude of remote sensing and GIS datasets (i.e., Normalized Difference Vegetation Index (NDVI), land cover datasets, and park layers) can be uploaded into these packages to provide objective measures of green cover in countries around the world [1]. Buffer tools (the "Buffer (Analysis)" toolkit in ArcGIS) can then calculate the percentage of greenspace—or relative "greenness" — within a specified geographic polygon, for example, the area surrounding a person's house.

The results of at least three studies using GIS buffer tools provide some evidence that greenness at any buffer size predicts physical health equally well. A national survey of physical activity and urban greenspace in Canada, for example, found that $30 \mathrm{~m}$ buffers predicted health as well as $500 \mathrm{~m}$ buffers [3]. Another study of greenness and air pollution exposure during pregnancy found that $100 \mathrm{~m}$, $250 \mathrm{~m}$, and $500 \mathrm{~m}$ buffers predicted birth and development outcomes similarly well [4]. A second study on birth and development outcomes and greenness found that $100 \mathrm{~m}$ and $500 \mathrm{~m}$ buffers had similar results [5]. What these studies fail to answer, however, is, does the impact of greenness on physical health plateau at a particular buffer size? To answer this question, one can compile these findings with those of other studies that examine greenness within larger buffer zones and look for trends across the studies.

A review of GIS buffer studies is valuable despite the recent advances in activity tracking that provide potentially more accurate measurements of the natural/built environment available to people [6]. For example, tracking with global positioning system (GPS) units can accompany individuals' whose physical activity is being tracked. The trajectories recorded from these units help to create neighborhood areas that encompass trips taken by individuals throughout their everyday life. As such, the area in which greenness is examined with GPS units includes both the residential and non-residential environments to which individuals are exposed-such as farther-away but regularly-visited parklands-and therefore considers the critical factor pertaining to which greenspaces are accessible along transportation routes [7]. Buffers created with distances set by researchers in GIS systems, in contrast, are artificially created and may over or under-estimate the range available to-and used by-residents. On the other hand, GPS is an approach being adopted in an only limited number of public health fields of research, primarily physical activity research (i.e., [8-11]), and several recent studies still use artificially-created buffers (i.e., [12-14]). Providing every individual in a sample population with GPS units is not feasible for all study designs, geographic contexts, study populations, and sample sizes. In order to review the available evidence on greenness around a person's home, it is, therefore, important to conduct a systematic review of artificially-created buffers in GIS.

We reviewed the body of literature that uses greenness buffer analyses to better understand at what distance greenness best predicts physical health. To identify this body of work, we included only those analyses that (1) used GIS buffers to estimate residential greenness; (2) used statistical analyses that calculated the significance of the greenness-physical health relationship; and (3) were peer-reviewed articles published in English between 2007 and May 2017. Our objective was to identify which buffer sizes were supported by the literature as having the strongest theoretically expected relationships between greenness and physical health —-that is, findings where greater greenness correlated with better physical health.

\section{Methods}

All steps in our review process were conducted in accordance with the Preferred Reporting Items for Systematic Reviews and Meta-Analyses (PRISMA) guidelines [15]. The screening and analyzing of data were conducted in Microsoft Excel for Mac. 


\subsection{Literature Search}

We searched Web of Science to identify relevant articles published in English between 2007 and May 2017. Search terms included "greenness" measures, GIS datasets and analytical techniques, and physical health outcomes (see Appendix A, Table A1 for a list of all terms).

\subsection{Selection Criteria}

To extract data from multiple analyses included in articles, we conducted a two-step selection process. First, we selected those articles with an overall focus and at least one reported analysis that was relevant for this review. Next, we selected the relevant analyses from each of these articles.

\subsubsection{Article Selection}

Initial eligibility of articles was determined by reviewing their titles and abstracts. The full text of the remaining articles was then screened for three criteria. First, the focus of the article had to measure the impact of greenness on physical health using GIS buffer analyses. "Greenness" could include percent green cover, green space, or parks; the number of green spaces, parks, or open space within the buffer; or the standard deviation of greenness or landscape indices. Second, the authors conducted inferential statistical analyses to measure the relationship between these variables; and, third, statistical significance tests ( $p$-values) resulting from these analyses were performed.

\subsubsection{Analysis Selection}

Next, we screened analyses within eligible articles to determine which analyses were appropriate to examine in this review. Screening criteria included: (1) GIS buffers used residential center points in GIS buffer analyses, rather than school or workplace center points; and (2) the dependent variable was a physical, not a mental health outcome. No exclusionary criteria were set for the range of ages studied. Analyses included, therefore, used buffers around physical addresses of homes or centers of politically defined geographic areas enclosing homes (i.e., census tracts) and surveyed sample ages across the lifespan, from infants to elders.

\subsection{Data Extraction}

Most data were extracted at the analysis, not the article, level. Only first author, publication year, and article title were identified at the article level. In contrast, a wide range of characteristics were identified at the analysis level, including article information (first author, publication year, and article title); greenness type ("greenness", tree canopy, greenspace or open space, or park); physical health outcome; objectivity of physical health outcome; country/countries covered by sample population; age range(s) of sample population; size of sample; confounds included (i.e., age, sex, race, income, employment, education, urbanity, etc.); presence of spatial autocorrelation test(s); center point of GIS buffer (home, postal code, or census tracts/blocks); type of GIS buffer (see below); size of buffer in meters; presence or absence of statistically significant association between health outcome and greenness; and direction of significant associations between health outcome and greenness.

The type of buffer data extracted concerned whether the buffer was made in one of two ways. Radial buffers estimate greenness "as the crow flies" around a point. In this case, when the researcher specified a radial distance, the GIS software drew a circle (circular buffer) with a radius equal to that value. The circle was centered on a specified point-often an individual's home address or the center of a geographic zone within which the individual lives (i.e., census tract or postal code). In contrast, network buffers estimate greenness along transportation pathways. The GIS software determines the network buffers, after the researcher specifies the distance, along all available walking or driving routes, based on road network GIS data. This process results in a polygon (network buffer), which is not perfectly circular in shape, because the perimeter of the buffer represents points that are within a set distance along trails and roads (Figure 1). 
Several analytical characteristics were reported in detail in articles, and we coded these into broader categories for this review. Physical health outcomes were divided into 18 categories. These were adapted from categories identified in previous greenness and health literature reviews $[1,16,17]$. The manner of data collection for physical health outcomes was grouped into three categories, based on whether data were objective (i.e., biomarkers, vital signs), expert or clinician diagnoses (i.e., electronic medical records), or subjective (i.e., self-reported health questionnaires). Lastly, we grouped age ranges into five categories: samples with individuals less than one year old (infants), 2-10 years old (children), 11-17 years old (youth), 18-79 (adults), and 80 years and over (elders).

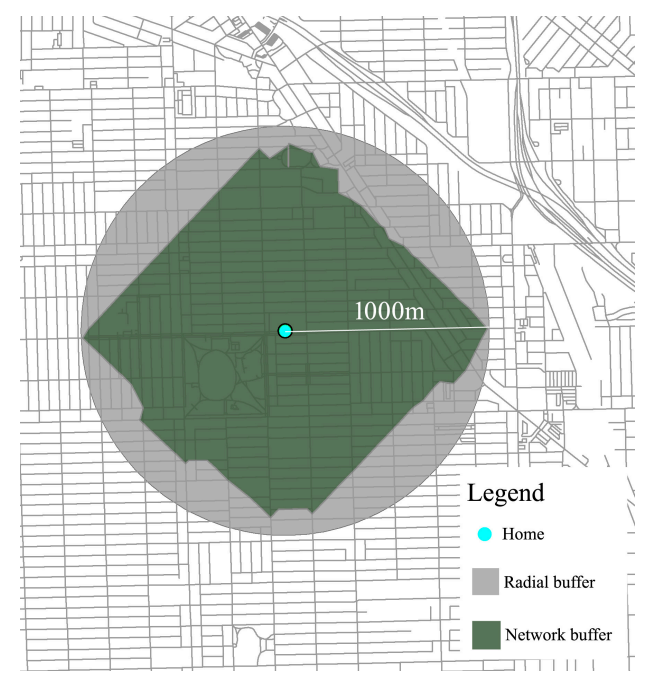

Figure 1. Buffer analyses are tools to calculate the "greenness" of residential environments. Buffers are drawn two ways. Radial buffers (outer circle in gray) show greenness in the circle of a specified radius around a center point-in this case, $1000 \mathrm{~m}$. Network buffers (inner polygon shape in green) show greenness in the region within a specified walking or driving distance of a center point.

\subsection{Evaluation of Possible Bias}

Our focus was on evaluating analyses with higher or lower levels of potential bias. The items we evaluated were individual analyses, not articles. Thus, our evaluative judgments in this review do not cover the articles in their entirety. It is possible that any given article had some analyses that could be judged as having higher potential bias and others as lower.

To identify possible criteria that would demonstrate potential bias, we consulted criteria used in prior systematic literature reviews on greenness and human health outcomes $[18,19]$. We found that some prior criteria (i.e., multiplicity of outcome variables within a single article) did not apply to our unit of examination - that is, analyses rather than articles-and other criteria represented characteristics of potential bias which we had already excluded in our screening process (i.e., expert assessments of "greenness" versus land-cover maps or satellite system assessments). We narrowed our criteria to two items: did the analysis include a subjective measure of physical health as its dependent variable; and did the analysis account for the critical confounding variable-income? We chose the latter criteria because a robust body of work demonstrates that this variable, more than any other, partially explains the relationship between greenness and health outcomes [1,16]. Not including a measure of income-such as socio-economic status or the common proxy, level of education-overestimates positive relationships between greenness and health.

Our chosen criteria for assessing bias (subjective measures of health and controls for socio-economic status) allowed us to rank articles into three levels. We designated analyses that did not meet either of the criteria as more likely to be biased. We designated analyses that met one criteria as less likely to be biased and those that met both criteria as least likely to be biased. 


\section{Results}

\subsection{Subsection}

The initial database search produced 311 records, but the majority were not salient for this review. The full texts of 68 articles were reviewed for eligibility, and 47 met our criteria for inclusion (see Figure 2 for details on articles removed at each step of the screening process).

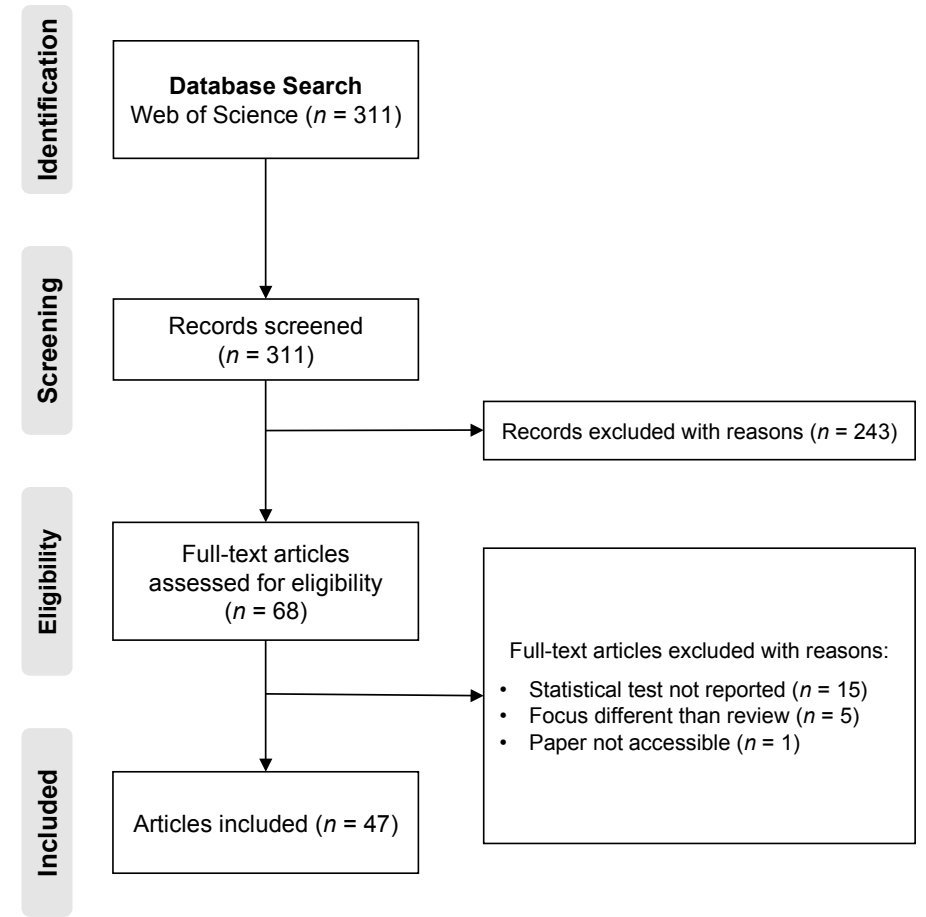

Figure 2. Flow diagram of the screening of articles considered for inclusion in this review - conducted using the PRISMA process.

Articles contained between one [20] and 44 [21] analyses that met our inclusion criteria. In total, 260 analyses were included in this review (for a complete listing of articles and their analyses, see Appendix A, Table A2).

\subsection{Descriptive Characteristics of Articles}

We found that the number of published articles on the use of GIS buffers to estimate the impact of greenness on physical health increased over time. The majority of articles identified in this review were published in the last four years (Figure 3).

We also found that articles examined populations from around the world. In total, 17 countries were represented: Australia, Belgium, Brazil, Canada, Colombia, Czech Republic, Denmark, Germany, Hong Kong, Lithuania, Mexico, Netherlands, New Zealand, Spain, Sweden, the United Kingdom, and the United States (Figure 4). Populations from the United States and Australia were most frequently examined. The former was studied in nine articles and the latter in eight articles. The next most commonly studied populations were from the Netherlands, Germany, and Canada, which were examined in six articles each. 


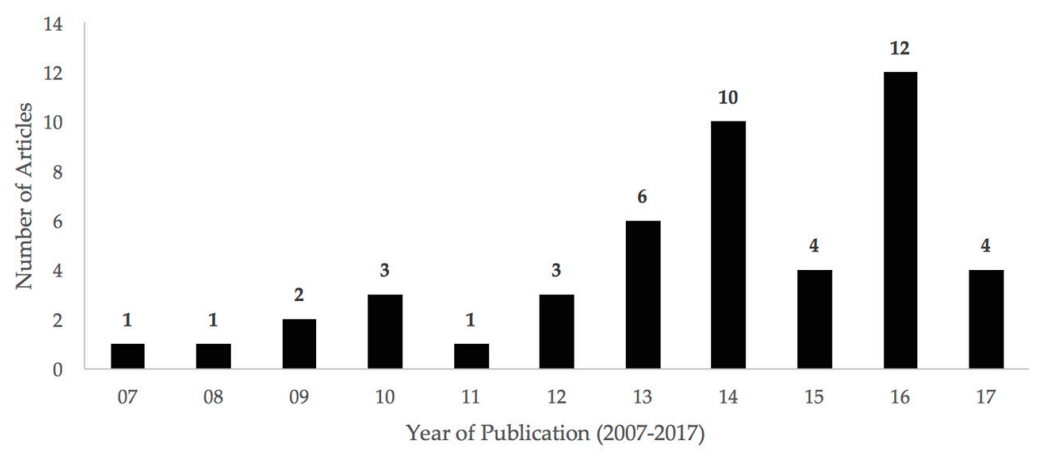

Figure 3. The number of articles using GIS buffer analyses to estimate the impact of greenness on physical health has increased over time, especially since 2013. Data for 2017 is incomplete because the review only included articles published before May 2017.

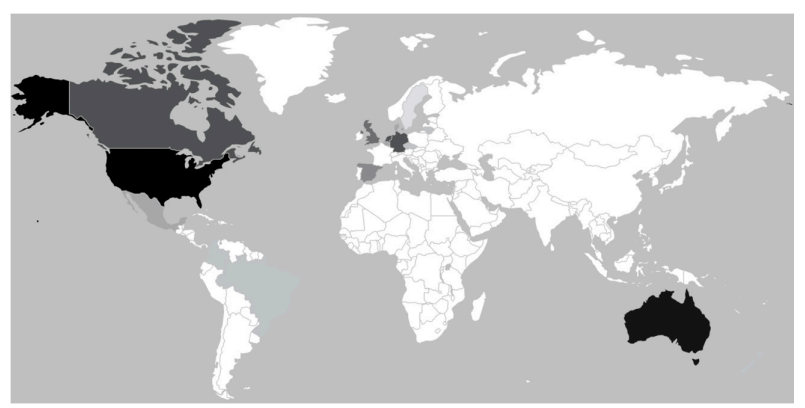

Figure 4. Articles studied populations from 17 countries, with the United States and Australia most commonly studied. Darker colors represent more articles on populations from that country.

\subsection{Descriptive Characteristics of Analyses}

Analyses used a wide range of sample sizes and ages (Table 1). The smallest sample was 61 [22] and the largest was 345,143 [21]. Over two-thirds of analyses included at least 2500 individuals and one-third included at least 10,000. Adults were the most commonly studied age range, with $30 \%$ of analyses studying exclusively $18-79$ year olds and another $36 \%$ studying $18-79$ year olds as well as youth and/or elders.

Table 1. Sample characteristics of analyses $(n=260)$ included in review.

\begin{tabular}{lcc}
\hline & Number of Analyses & Percent of Analyses \\
\hline Size & 36 & \\
Less than 1000 & 41 & $14 \%$ \\
1000 to 2500 & 86 & $16 \%$ \\
2501 to 5000 & 12 & $33 \%$ \\
5001 to 10,000 & 26 & $5 \%$ \\
10,001 to 50,000 & 9 & $10 \%$ \\
50,001 to 100,000 & 4 & $3 \%$ \\
100,001 to 200,000 & 46 & $2 \%$ \\
More than 200,000 & & $18 \%$ \\
\hline Age & 4 & \\
Infants only & 6 & $2 \%$ \\
Children only & 23 & $2 \%$ \\
Youth only & 79 & $9 \%$ \\
Adults only & 5 & $30 \%$ \\
Elders only & 3 & $2 \%$ \\
Infants and children & 43 & $1 \%$ \\
Children and youth & 50 & $17 \%$ \\
Youth, adults, and elders & 47 & $19 \%$ \\
Adults and elders & $18 \%$ \\
\hline
\end{tabular}


Less than one-half of analyses (45\%) displayed a likelihood of bias (Table 2), of which, less than $1 \%$ displayed a strong likelihood of bias. Nearly two-thirds (65\%) included objective measures or expert/clinical diagnoses of physical health. Income measures were even more common: $85 \%$ of analyses included education as a proxy for income, and $17 \%$ included income measures.

Table 2. Quality of measures in analyses.

\begin{tabular}{|c|c|c|}
\hline & Number of Analyses & Percent of Analyses \\
\hline \multicolumn{3}{|l|}{ Health data quality } \\
\hline Objective & 115 & $44 \%$ \\
\hline Expert or clinical diagnosis & 55 & $21 \%$ \\
\hline Subjective & 90 & $35 \%$ \\
\hline \multicolumn{3}{|l|}{ Greenspace measure } \\
\hline Greenness $^{\mathrm{a}}$ & 124 & $48 \%$ \\
\hline Green or open space ${ }^{b}$ & 110 & $42 \%$ \\
\hline Park ${ }^{b}$ & 23 & $9 \%$ \\
\hline Tree canopy ${ }^{b}$ & 3 & $1 \%$ \\
\hline \multicolumn{3}{|l|}{ Confounds included } \\
\hline Education level & 221 & $85 \%$ \\
\hline Sex & 220 & $85 \%$ \\
\hline Age & 209 & $80 \%$ \\
\hline Smoking behavior & 78 & $30 \%$ \\
\hline Employment status & 74 & $28 \%$ \\
\hline Urbanity & 68 & $26 \%$ \\
\hline BMI & 62 & $24 \%$ \\
\hline Race/ethnicity & 60 & $23 \%$ \\
\hline Marital status & 49 & $19 \%$ \\
\hline Income & 44 & $17 \%$ \\
\hline \multicolumn{3}{|l|}{ Bias Evaluation } \\
\hline More likely to be biased & 2 & $1 \%$ \\
\hline Less likely to be biased & 114 & $44 \%$ \\
\hline Least likely to be biased & 144 & $55 \%$ \\
\hline
\end{tabular}

Age and sex were additional common confounds, included in at least $80 \%$ of analyses. All other confounds were represented in less than one-third of analyses.

In regards to the methodological choices made in buffer analyses, we found that $73 \%$ of analyses used home addresses as buffer centers. Further, $17 \%$ of analyses controlled for spatial autocorrelation. A nearly equal number of analyses used "greenness" (48\%) and/or green space or open space metrics (42\%).

\subsection{Consistency of Greenness-Physical Health Link}

Only $35 \%$ of analyses $(n=91)$ demonstrated statistically significant relationships between greenness and improved physical health. The majority $(62 \%, n=161)$ demonstrated no significant relationship between these variables, and a few $(3 \%, n=8)$ even found a significant relationship in the opposite direction-more green being tied to worse physical health.

Findings were similar across the lifespan. Thirty-seven percent $(n=49)$ of the 131 analyses that studied only adult or adult and elder populations found significant positive effects of greenness, and $2 \%(n=3)$ reported negative effects of greenness. Similarly, $29 \%(n=22)$ of the 75 analyses that studied only children, youth, and/or infants-but not only infants-reported significant positive effects. Seven percent $(n=5)$ of these analyses reported negative effects. 


\subsection{Specific Physical Health Outcomes Studied}

Three outcomes accounted for over one-half of the dependent variables studied in analyses. These commonly-studied outcomes included physical activity (the dependent variable in $25 \%$ of analyses, $n=65)$, birth and developmental outcomes $(16 \%, n=41)$, and cardiovascular outcomes $(13 \%, n=33)$. Obesity and atopy (asthma, allergies, and eczema) were also commonly studied; each was used in approximately $10 \%$ of analyses ( $n=26$ and 24 , respectively). General health (i.e., self-reported health questionnaires asking respondents "in general, how would you rate your health?") was studied in $6 \%$ $(n=16)$ of analyses. Twelve other physical health outcomes were studied in $5 \%$ or less of analyses each $(n=2$ to 12$)$.

Nine outcomes showed that greenness improved health in one-half or more of analyses, but most of these outcomes were studied just a few times (Table 3). Obesity and diabetes were the only two outcomes that improved with greenness in over one-half of a more substantial number of analyses $(n>10)$. Analyses using the three most commonly studied outcomes (physical activity, birth and developmental outcomes, and cardiovascular disease) found significant positive correlations between greenness and physical health just 18 to $34 \%$ of the time. When we examined the most commonly studied outcome (physical activity), we found that objective measurements using accelerometer devices showed significant associations almost twice as frequently as subjective, self-report measures.

Table 3. Frequency of analyses finding that greenness improves specific outcomes.

\begin{tabular}{lccc}
\hline \multicolumn{1}{c}{ Outcome } & $\begin{array}{c}\text { Total Number of } \\
\text { Analyses }\end{array}$ & $\begin{array}{c}\text { Number with } \\
\text { Significant Findings }\end{array}$ & $\begin{array}{c}\text { Percent with } \\
\text { Significant Findings }\end{array}$ \\
\hline Physical activity (PA) & 65 & 22 & $34 \%$ \\
Objective PA measures & 21 & 10 & $48 \%$ \\
(i.e., accelerometer) & & & \\
Subjective PA measures & 44 & 12 & $27 \%$ \\
(i.e., self-report exercise frequency) & 41 & 14 & $34 \%$ \\
Birth and developmental outcomes & 33 & 6 & $18 \%$ \\
Cardiovascular outcomes & 26 & 13 & $50 \%$ \\
Obesity & 24 & 1 & $4 \%$ \\
Atopy & 16 & 7 & $44 \%$ \\
General health & 12 & 4 & $58 \%$ \\
Diabetes & 12 & 4 & $33 \%$ \\
Musculoskeletal complaints & 6 & 4 & $67 \%$ \\
Cancer & 4 & 1 & $100 \%$ \\
Mortality & 4 & 3 & $25 \%$ \\
Upper respiratory tract infection & 3 & 1 & $100 \%$ \\
Vision & 2 & 2 & $50 \%$ \\
Acute urinary tract infection & 2 & 1 & $100 \%$ \\
Infectious disease of intestinal canal & 2 & 0 & $50 \%$ \\
Migraine & 2 & 1 & $0 \%$ \\
Respiratory disease & 2 & 0 & $50 \%$ \\
Vertigo & 2 & $0 \%$ \\
Vitality & & & \\
\hline
\end{tabular}

\subsection{Buffer Sizes Used}

Buffers between 1000-1999 $\mathrm{m}$ in size were most commonly used. This size represented nearly one-third of all analysis $(n=84)$. The next most common were 500-999 m buffers, which were used in approximately one-quarter of analyses ( $n=67)$. Other buffer size ranges (less than $250 \mathrm{~m}, 250$ to $499 \mathrm{~m}$, and greater than $2000 \mathrm{~m}$ ) were used at similar frequencies: between $32(12 \%)$ and $41(16 \%)$ of analyses. 


\subsection{Buffer Size and Physical Health}

The relative number of analyses that tied greenness to physical health grew as the buffer size increased, but only up to $1999 \mathrm{~m}$ (Figure 5). In analyses with buffers of less than $250 \mathrm{~m}, 24 \%$ of studies reported that greenness improved physical health. This percent increased for analyses with buffers 250-499 m (34\%), 500-599 m (39\%) and 1000-1999 m (42\%), but then dropped substantially for analyses with buffers of $2000 \mathrm{~m}$ or more $(25 \%)$.

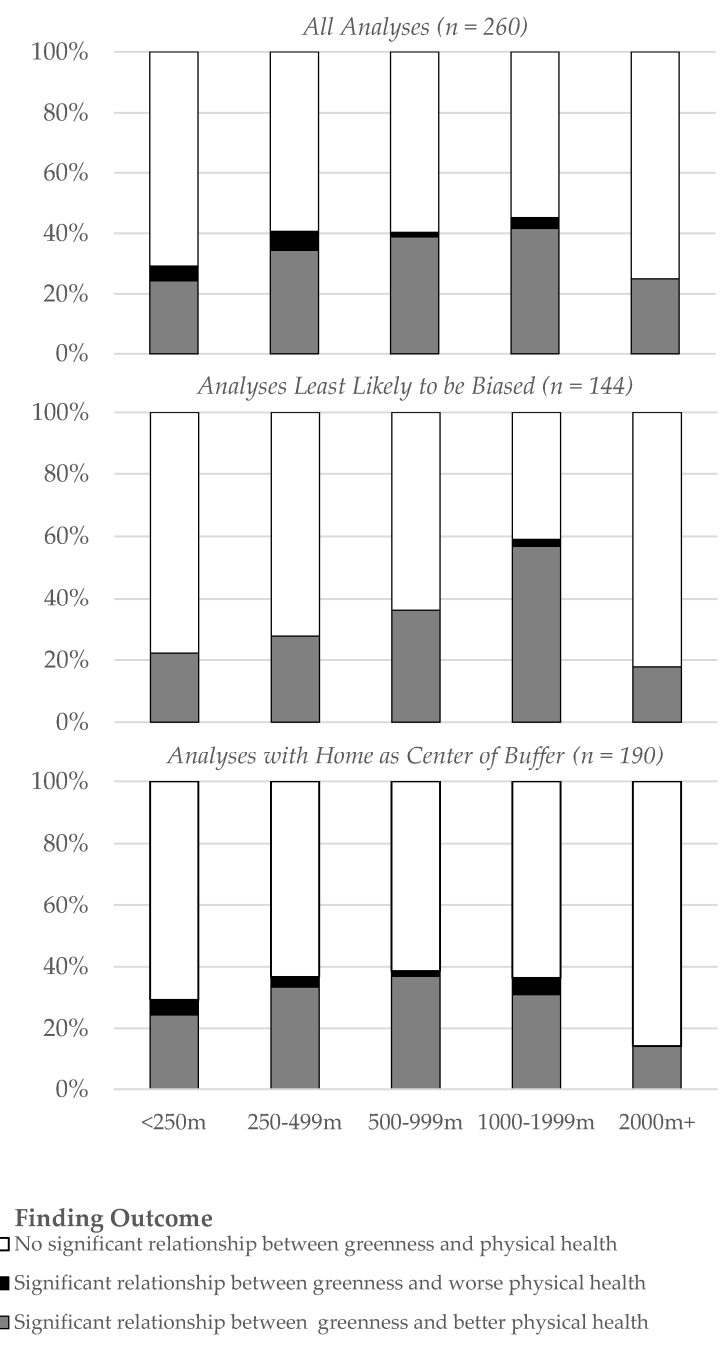

Figure 5. Percent of analyses showing statistically significant relationships between greenness and physical health improvement increases as buffer size increases, but only to a point. In all analyses reviewed (top), the percent of significant findings increased up to 1000-1999 $\mathrm{m}$ buffers, but then decreased at larger buffer sizes. This trend was exaggerated when examining only those analyses least likely to be biased (middle), as indicated by their use of objective health measures and the inclusion of income or education as a confounding factor. Analyses that used buffers centered on home addresses-rather than postal codes or census tracts-showed a different tipping point (bottom). In this subsample, analyses demonstrated that greenness improves physical health in buffers up to 500-999 $\mathrm{m}$ in size-not 1000-1999 m.

We tested whether this trend held with two subsamples of analyses, both of which included smaller but more reliable, valid measures of greenness. First, we restricted our sample to the 144 analyses that we judged as least likely to be biased. We found that the previously described trend was more pronounced in this subsample: the percent of analyses tying greenness to health 
increased from $22 \%$ with buffers of less than $250 \mathrm{~m}$, to $57 \%$ for buffers between 1000-1999 $\mathrm{m}$ in size. Second, we restricted our sample to the 190 analyses that used individuals' home addresses for buffer centers. This subsample again suggested that increasing numbers of analyses found positive ties between greenness and physical health as buffer size increases, but it plateaued at 500-999 m buffers. The percent of significant findings increased from $26 \%$ (buffers of less than $250 \mathrm{~m}$ ) to $38 \%$ (buffers between 500-999 m), and then decreased to 33\% (buffers between 1000-1999 m).

\section{Discussion}

The objective of this systematic literature review was to discover trends in buffer analyses reported in peer-reviewed journal articles on residential greenness and physical health. We identified 260 analyses in 47 articles that met our inclusion criteria.

These analyses showed the following trend: the likelihood of greenness predicting physical health increased as the size of the buffer increased. However, this trend plateaued at buffers between 1000-1999 m in size. Buffers of $2000 \mathrm{~m}$ and above were less likely to show greenness predicting physical health than all smaller buffers sizes.

This trend toward 1000-1999 m buffers best predicting physical health did not hold for the subsample of analyses that used home addresses as the center point of buffers. In $27 \%$ of the analyses in this review, researchers fixed buffers not around homes but around geographic midpoints of geographic regions (i.e., census tracts or postal codes). We examined trends when these analyses were excluded because buffers centered on homes were more reliable indicators of residential greenness than buffers centered on the center of the political boundary in which an individual resides. In this subsample, we found that increasing buffer sizes corresponded with increasing likelihood of greenness predicting physical health, and we further found that this trend plateaued at a certain size. The plateau size, however, was smaller than our earlier-found trend: buffers between 500-999 $\mathrm{m}$ in size and centered around homes best predicted physical health. Buffers smaller than $500 \mathrm{~m}$ and greater than $999 \mathrm{~m}$ were less likely to predict physical health.

These trends toward larger buffer size better predicting physical health do not indicate that nearby greenspace (i.e., a park located within a $250 \mathrm{~m}$ buffer from a house) is less predictive of physical health than distant greenspace. A $1000 \mathrm{~m}$ buffer around a house includes greenspace located in smaller, nested buffers around that house, as well as greenspace in distant edges of that buffer (i.e., a park $950 \mathrm{~m}$ away from buffer center). Thus, a $1000 \mathrm{~m}$ buffer includes all greenspaces captured in the $50 \mathrm{~m}-, 250 \mathrm{~m}-$, and $500 \mathrm{~m}$ buffers. The extent of greenness for a $1000 \mathrm{~m}$ buffer, therefore, is the total green/open land uses within this circular area, divided by the total area of the buffer.

What these findings do indicate is that larger buffers are more likely to predict physical health than smaller buffers, given that these two buffers have equal percentages or densities of green cover. That is, individuals with high densities of green cover in their broader neighborhoods are more likely to have better physical health than individuals with high densities of green cover around their homes but low densities of green cover in their broader neighborhoods.

It should be noted that for smaller and larger buffers to have the same relative amount of green cover requires substantially different actual amounts of green cover. Let us consider a scenario where two buffers both have 50\% green cover. The larger buffer has a $1000 \mathrm{~m}$ radius and covers a circular area of approximately $3,140,000 \mathrm{~m}^{2}$. The smaller buffer has a $250 \mathrm{~m}$ radius and covers an area of approximately $200,000 \mathrm{~m}^{2}$. Given that both of these buffers have $50 \%$ green cover, the $1000 \mathrm{~m}$ buffer would include $1,570,000 \mathrm{~m}^{2}$ (nearly 400 acres) of greenspace, but the $25 \mathrm{~m}$ buffer would only include 100,000 $\mathrm{m}^{2}$ (approximately 25 acres) of greenspace. Because the smaller buffer analysis does not describe green cover beyond this relatively small area, it cannot evaluate whether the broader neighborhood includes those additional 1,470,000 $\mathrm{m}^{2}$ of green cover represented in the $1000 \mathrm{~m}$ buffer analysis. From this example, the power of larger buffers to predict much larger tracts of green space coverage becomes evident. Our findings - that buffers of increasing size better predict physical health than smaller buffers-may, therefore, be the result of larger buffers' increased power to measure larger 
tracts of greenspace in a neighborhood. Importantly, though, our finding that buffers of over $2000 \mathrm{~m}$ drop in predictive power provides some evidence of a dosage effect of residential greenness. This review suggests that green cover farther away than $2000 \mathrm{~m}$ (a 20-min moderately-paced walk) has less impact on physical health than green cover located nearby.

Although this review found that a majority of buffer analyses did not report positive findings between greenness and physical health, this finding should not be considered conclusive. Many of the analyses in this review examined health outcomes for which multiple other reviews find consistent ties between greenness and physical health-namely physical activity, birth and developmental outcomes, and cardiovascular outcomes [1,16,23-25]. The analyses in this review represent a relatively small sample of articles using a single analytic tool to estimate residential greenness. The low number of positive findings in this review, therefore, is only a slice of the available evidence on the link between nature and physical health.

This review reported several characteristics of buffer analyses that indicate this field of literature is robust and in general is growing stronger. The number of analyses is increasingly nearly every year, and these analyses are being conducted globally—although they are concentrated in Australia, North America, and Western Europe. Very few analyses fail to use objective measures of physical health and controls for income. A considerable number of analyses use substantial sample sizes over 10,000, and the majority of analyses use sizes of at least 2500 . These samples represent populations across the lifespan, from infants to elders. The only major limitation we identified is the relatively low number of analyses that consider or control for spatial autocorrelation.

The findings in this review are limited primarily by its scope of studies included. A growing body of GIS buffer analyses considers other health outcomes and may help explain how distance within which greenness is measured influences health. For instance, at least three articles have tied academic achievement to school greenness [26-28], and another thirteen articles have tied mental health to residential greenness [18] with buffer analyses. Albeit, the mechanisms by which greenness improves these outcomes may be different than those by which greenness improves physical health. For example, residential greenspace may support physical health primarily by providing opportunities for physical activity [29] or by improving immune functioning [16]. On the other hand, greenspace may reduce anxiety and depression primarily by reducing maladaptive patterns of circular, negative thought called ruminative brooding [30]. Different mechanisms may require different amounts of greenness at different distances from a person's home. It is feasible that views of trees from windows may be most important for reducing depression-much more so than large green spaces accessible by only a 20-min walk. Even so, it would enhance practitioners' understanding of the importance of greenspace at different distances from a person's home address if additional studies with outcomes other than physical health were reviewed in a way similar to that of this study.

We recommend that future researchers using GIS buffers estimate greenspace's impact on health to try to resolve the unique impact of greenness in nested, rather than overlapping, buffers. All analyses in this review used larger buffer areas that overlapped with smaller ones. As a result, we do not know the unique contribution of farther-away greenspace, that is, the greenspace identified in the difference between larger and smaller buffer areas. Analyses that used a nested buffer pattern, wherein a $250 \mathrm{~m}$ buffer region is excluded from $500 \mathrm{~m}$ buffer analyses, and $250 \mathrm{~m}$ and $500 \mathrm{~m}$ buffer regions are excluded from $1000 \mathrm{~m}$ buffer analyses, would enhance our understanding of at what distance greenness best predicts improvements in physical health.

Another notable recommendation for future research is to use network buffers, which estimate greenness that is physically accessible to people along walking routes. Especially, in the physical activity research domain, the use of network buffers has recently become popular to accurately estimate the impact of greenness on walking $[12,13,31]$. Other physical health research should apply network buffers in future research to weight the access to reachable greenspaces or parks by walking, which may affect various physical health outcomes. 
Also, future research can focus on other GIS methods to define exposure to greenness areas. Recent studies have used GPS units to better understand daily travels of individuals and assess exposures to non-residence environments including workplaces, shopping places, and other areas that play important roles in daily life beyond the neighborhood area immediately surrounding the home [32-35]. These exposure areas can be estimated using a broad range of different GIS analysis beyond buffers, such as kernel densities and neighborhood delineations [36-38]. Which methods provide the most reliable and valid associations between greenspaces and physical health, however, has not been adequately reviewed. Therefore, additional research on physical health findings related to greenness using a variety of GIS methods is warranted.

\section{Conclusions}

This review has demonstrated that greenness measured at larger distances from people's home environments—specifically buffers between $500 \mathrm{~m}$ and $1999 \mathrm{~m}$ in size-predicted physical health better than smaller buffers. Because the analyses included in this review used overlapping rather than nested buffers, we were unable to evaluate the impact of farther-away versus closer greenspaces.

Acknowledgments: This work was supported by the 12-JV-11242309-084 Joint Venture Agreement between the University of Illinois at Urbana-Champaign and the United States Department of Agriculture (USDA), Forest Service Northern Research Station.

Author Contributions: Matthew Browning and Kangjae Lee conceived and designed the study; Kangjae Lee conducted the systematic review and analyzed the data; Matthew Browning wrote the paper; Matthew Browning and Kangjae Lee reviewed and refined the paper.

Conflicts of Interest: The authors declare no conflict of interest.

\section{Appendix A}

Table A1. Search terms used to identify relevant articles for the review.

\begin{tabular}{|c|}
\hline Measure of Greenness \\
\hline $\begin{array}{l}\text { 1. Green space } \\
\text { 2. Greenness } \\
\text { 3. Greenspace * } \\
\text { 4. Park* } \\
\text { 5. (1 OR } 2 \text { OR } 3 \text { OR 4) AND }\end{array}$ \\
\hline GIS Analysis \\
\hline $\begin{array}{l}\text { 1. Geographic Information System * } \\
\text { 2. GIS } \\
\text { 3. Landsat } \\
\text { 4. LiDAR } \\
\text { 5. NDVI } \\
\text { 6. Normalized Difference Vegetation Index } \\
\text { 7. Radius } \\
\text { 8. (1 OR } 2 \text { OR } 3 \text { OR } 4 \text { OR } 5 \text { OR } 6 \text { OR 7) AND }\end{array}$ \\
\hline Physical Health Outcome \\
\hline $\begin{array}{l}\text { 1. Allerg* } \\
\text { 2. Asthma } \\
\text { 3. BMI } \\
\text { 4. *Morbidity } \\
\text { 5. Mortality } \\
\text { 6. Obesity } \\
\text { 7. Physical activity } \\
\text { 8. Physical health } \\
\text { 9. Pregnancy } \\
\text { 10. (1 OR 2 OR 3 OR 4 OR 5 OR 6 OR } 7 \text { OR } 8 \text { OR 9) }\end{array}$ \\
\hline
\end{tabular}

* as a wildcard character, the asterisk matches one or more characters. 
Table A2. Articles included in review.

\begin{tabular}{|c|c|c|c|c|c|c|c|c|c|c|}
\hline \multirow{2}{*}{ Authors (Year) } & \multirow{2}{*}{$\begin{array}{c}\text { \# of } \\
\text { Analyses }\end{array}$} & \multicolumn{3}{|c|}{ Sample Characteristics } & \multirow{2}{*}{$\begin{array}{l}\text { Greenness } \\
\text { Type(s) }\end{array}$} & \multicolumn{3}{|c|}{ Buffer Characteristics } & \multirow{2}{*}{ Confound(s) } & \multirow{2}{*}{ Health Outcome(s) } \\
\hline & & Region(s) & Ages & Size & & Type & Size(s) & Center & & \\
\hline $\begin{array}{l}\text { Andrusaityte } \\
\text { et al. (2016) [39] }\end{array}$ & 3 & Lithuania & $4-6$ & 1489 & Greenness & Radial & $\begin{array}{l}100 \mathrm{~m} \\
300 \mathrm{~m} \\
500 \mathrm{~m}\end{array}$ & Home & $\begin{array}{l}\text { Education, smoking, mother's age at child birth, } \\
\text { parental asthma, breastfeeding, antibiotic use, cat, } \\
\text { ambient PM2.5, } \mathrm{NO}_{2}\end{array}$ & Proportions of children with asthma \\
\hline $\begin{array}{l}\text { Astell-Burt } \\
\text { et al. (2014) [40] }\end{array}$ & 2 & Australia & $45+$ & 203,883 & Greenspace & Radial & $1 \mathrm{~km}$ & Postal code & $\begin{array}{l}\text { Age, sex, race, income, education, Body Mass } \\
\text { Index (BMI), employment, country of birth, } \\
\text { couple status, psychological distress, language } \\
\text { other than English, social interactions, } \\
\text { neighborhood affluence, geographic remoteness }\end{array}$ & $\begin{array}{l}\text { Walking; Moderate-to-vigorous physical } \\
\text { activity (MVPA) }\end{array}$ \\
\hline $\begin{array}{l}\text { Bijnens et al. } \\
\text { (2015) [41] }\end{array}$ & 3 & Belgium & Maternal age & 211 & Greenspace & Radial & $\begin{array}{l}3 \mathrm{~km} \\
4 \mathrm{~km} \\
5 \mathrm{~km}\end{array}$ & Home & $\begin{array}{l}\text { Age, sex, education, smoking, birth weight, } \\
\text { chronicity, maternal age, neighborhood } \\
\text { socio-economic status (SES) }\end{array}$ & Telomere length \\
\hline $\begin{array}{l}\text { Bodicoat et al. } \\
\text { (2014) [42] }\end{array}$ & 6 & United Kingdom & $20-75$ & 10,476 & Greenspace & $\begin{array}{l}\text { Radial } \\
\text { Network }\end{array}$ & $\begin{array}{l}800 \mathrm{~m} \\
3 \mathrm{~km} \\
5 \mathrm{~km}\end{array}$ & Postal code & $\begin{array}{l}\text { Age, sex, race, BMI, urbanicity, social deprivation, } \\
\text { physical activity, fasting glucose, } 2 \text { h glucose, total } \\
\text { cholesterol }\end{array}$ & Oral glucose or glycated hemoglobin \\
\hline $\begin{array}{l}\text { Cerin et al. } \\
\text { (2017) [13] }\end{array}$ & 4 & $\begin{array}{l}\text { Belgium, Brazil, } \\
\text { Colombia, Czech } \\
\text { Republic, Denmark, } \\
\text { Hong Kong, } \\
\text { Mexico, New } \\
\text { Zealand, United } \\
\text { Kingdom, U.S. }\end{array}$ & $18-66$ & 6712 & Parks & Network & $\begin{array}{l}500 \mathrm{~m} \\
1 \mathrm{~km}\end{array}$ & Home & Age, sex, marital status, education, employment & MVPA \\
\hline $\begin{array}{l}\text { Chen et al. } \\
\text { (2017) [43] }\end{array}$ & 3 & United States & 9-17 & 150 & Greenness & Radial & $250 \mathrm{~m}$ & Home & $\begin{array}{l}\text { Age, sex, race, income, family relationship, season } \\
\text { of visit, asthma severity, atopic status, inhaled } \\
\text { corticosteroid use, } \beta \text { agonist use }\end{array}$ & $\begin{array}{l}\text { Asthma control; Asthma functional } \\
\text { limitations; T-helper cell expression of } \\
\text { glucocorticoid receptors }\end{array}$ \\
\hline $\begin{array}{l}\text { Dadvand et al. } \\
\quad(2012)[4]\end{array}$ & 9 & Spain & $16+$ & 2393 & Greenness & Radial & $\begin{array}{l}100 \mathrm{~m} \\
250 \mathrm{~m} \\
500 \mathrm{~m}\end{array}$ & Home & $\begin{array}{l}\text { Sex, race, education, BMI, smoking, gestational } \\
\text { age, maternal age, weight gain during pregnancy, } \\
\text { alcohol consumption, parity, season of conception }\end{array}$ & $\begin{array}{l}\text { Birth weight; Birth head circumference; } \\
\text { Gestational age }\end{array}$ \\
\hline $\begin{array}{l}\text { Dadvand et al. } \\
\quad(2012)[5]\end{array}$ & 2 & Spain & Maternal age & 8246 & Greenspace & Radial & $100 \mathrm{~m}$ & Home & $\begin{array}{l}\text { Age, race, education, urbanicity, smoking, } \\
\text { employment, gestational age, neighborhood SES, } \\
\text { distance of residential place to major roads, } \\
\text { maternal booking weight, alcohol consumption, } \\
\text { parity, history of obstetrical-gynecological } \\
\text { pathologies, diabetes, sex of infant, use of assisted } \\
\text { reproductive techniques }\end{array}$ & Birth weight; Gestational age \\
\hline $\begin{array}{l}\text { Dadvand et al. } \\
\text { (2014) [44] }\end{array}$ & 20 & Spain & $9-12$ & 3178 & Greenness & Radial & $\begin{array}{c}100 \mathrm{~m} \\
250 \mathrm{~m} \\
500 \mathrm{~m} \\
1 \mathrm{~km}\end{array}$ & Home & $\begin{array}{l}\text { Age, sex, education, smoking, having older } \\
\text { siblings, type of school, parental history of } \\
\text { asthma, sport activity }\end{array}$ & $\begin{array}{l}\text { Asthma; Allergy; Sedentary behavior; } \\
\text { Obesity; BMI }\end{array}$ \\
\hline $\begin{array}{l}\text { Dadvand et al. } \\
\text { (2014) [45] }\end{array}$ & 5 & United Kingdom & Maternal age & 10,780 & Greenness & Radial & $\begin{array}{l}50 \mathrm{~m} \\
100 \mathrm{~m} \\
250 \mathrm{~m} \\
500 \mathrm{~m} \\
1 \mathrm{~km}\end{array}$ & Home & $\begin{array}{l}\text { Age, race, education, BMI, smoking, gestational } \\
\text { age, neighborhood SES, parity, alcohol } \\
\text { consumption, conception year, conception season }\end{array}$ & Birth weight \\
\hline
\end{tabular}


Table A2. Cont.

\begin{tabular}{|c|c|c|c|c|c|c|c|c|c|c|}
\hline \multirow{2}{*}{ Authors (Year) } & \multirow{2}{*}{$\begin{array}{c}\text { \# of } \\
\text { Analyses }\end{array}$} & \multicolumn{3}{|c|}{ Sample Characteristics } & \multirow{2}{*}{$\begin{array}{l}\text { Greenness } \\
\text { Type(s) }\end{array}$} & \multicolumn{3}{|c|}{ Buffer Characteristics } & \multirow{2}{*}{ Confound(s) } & \multirow{2}{*}{ Health Outcome(s) } \\
\hline & & Region(s) & Ages & Size & & Type & Size(s) & Center & & \\
\hline $\begin{array}{l}\text { Dadvand et al. } \\
\text { (2017) [46] }\end{array}$ & 5 & Spain & $7-10$ & 2727 & Greenness & $\begin{array}{l}\text { Radial } \\
\text { Network }\end{array}$ & $\begin{array}{l}50 \mathrm{~m} \\
100 \mathrm{~m} \\
250 \mathrm{~m} \\
500 \mathrm{~m}\end{array}$ & $\begin{array}{l}\text { Home/Surrounding } \\
\text { school/Commuting } \\
\text { school }\end{array}$ & $\begin{array}{l}\text { Age, sex, race, education, smoking, pregnancy } \\
\text { period, average screen time per week, Urban } \\
\text { Vulnerability Index }\end{array}$ & Use of spectacles \\
\hline $\begin{array}{l}\text { Demoury et al. } \\
\text { (2017) [47] }\end{array}$ & 4 & Canada & Under 76 & 3927 & Greenness & Radial & $\begin{array}{l}150 \mathrm{~m} \\
300 \mathrm{~m} \\
500 \mathrm{~m} \\
1 \mathrm{~km}\end{array}$ & Home & Age & Prostate cancer risk \\
\hline $\begin{array}{l}\text { Fuertes et al. } \\
(2014)[48]\end{array}$ & 3 & Germany & Birth-10 & 5803 & Greenness & Radial & $500 \mathrm{~m}$ & Home & $\begin{array}{l}\text { Age, sex, education, smoking, parental history of } \\
\text { atopy, older siblings, cohort }\end{array}$ & $\begin{array}{l}\text { Allergic rhinitis; Eyes and nose } \\
\text { symptoms; Aeroallergen sensitization }\end{array}$ \\
\hline $\begin{array}{l}\text { Fuertes et al. } \\
(2016)[49]\end{array}$ & 2 & $\begin{array}{l}\text { Sweden, Australia, } \\
\text { Netherland, } \\
\text { Canada, Germany }\end{array}$ & $6-8,10-12$ & 13,016 & Greenness & Radial & $500 \mathrm{~m}$ & Home & $\begin{array}{l}\text { Age, sex, education, smoking, parental atopy, } \\
\text { older siblings, intervention group, cohort, region, } \\
\text { birth weight and exposure, to furry pets and } \\
\text { mold/dampness in the home }\end{array}$ & $\begin{array}{l}\text { Allergic rhinitis; Aeroallergen } \\
\text { sensitization }\end{array}$ \\
\hline $\begin{array}{l}\text { Ghekiere et al. } \\
(2016)[50]\end{array}$ & 1 & Australia & $10-12$ & 677 & $\begin{array}{l}\text { Open } \\
\text { space }\end{array}$ & Radial & $800 \mathrm{~m}$ & Home & Age, sex, marital status, education, employment & Active transport trips \\
\hline $\begin{array}{l}\text { Gómez et al. } \\
\text { (2010) [51] }\end{array}$ & 2 & Columbia & $60+$ & 1966 & Park & Radial & $500 \mathrm{~m}$ & Postal code & $\begin{array}{l}\text { Age, sex, education, having a limitation to engage } \\
\text { in physical activity, proximity of a family member, } \\
\text { neighborhood SES }\end{array}$ & Walking \\
\hline $\begin{array}{l}\text { Gong et al. } \\
\text { (2014) [52] }\end{array}$ & 2 & United Kingdom & $66+$ & 1010 & Greenness & Radial & $400 \mathrm{~m}$ & Postal code & $\begin{array}{l}\text { Age, marital status, education, urbanicity, car } \\
\text { ownership, general health, psychological distress, } \\
\text { area deprivation }\end{array}$ & Participation in physical activity \\
\hline $\begin{array}{l}\text { Grazuleviciene } \\
\text { et al. (2015) [53] }\end{array}$ & 15 & Lithuania & Maternal age & 3292 & Greenness & Radial & $\begin{array}{l}100 \mathrm{~m} \\
300 \mathrm{~m} \\
500 \mathrm{~m}\end{array}$ & Home & $\begin{array}{c}\text { Age, sex, marital status, education, BMI, smoking, } \\
\text { employment, height, diabetes, chronic diseases, } \\
\text { parity, gestation duration, previous preterm birth, } \\
\text { paternal height, alcohol consumption, blood } \\
\text { pressure }\end{array}$ & $\begin{array}{l}\text { Low birth weight; Term low birth } \\
\text { weight; Preterm birth; Small for } \\
\text { gestational age; Birth weight }\end{array}$ \\
\hline $\begin{array}{l}\text { James et al. } \\
\text { (2016) [54] }\end{array}$ & 4 & United States & $30-55$ & 108,630 & Greenness & Radial & $\begin{array}{r}250 \mathrm{~m} \\
1250 \mathrm{~m}\end{array}$ & Home & $\begin{array}{l}\text { Race, marital status, education, BMI, urbanicity, } \\
\text { smoking, employment, pack-years of smoking, } \\
\text { neighborhood SES, address change, physical } \\
\text { activity, air pollution, social engagement, mental } \\
\text { health, region }\end{array}$ & Nonaccidental mortality \\
\hline $\begin{array}{c}\text { Janssen and } \\
\text { Rosu (2015) } \\
{[55]}\end{array}$ & 2 & Canada & $11-13$ & 5138 & Greenspace & Radial & $1 \mathrm{~km}$ & Postal code & $\begin{array}{l}\text { Sex, race, income, grader, perceived } \\
\text { neighborhood characteristics (safety, average } \\
\text { income, number of recreational facilities, \% of } \\
\text { developed parks, playgrounds, total road } \\
\text { distances), perceived family wealth, } \\
\text { neighborhood average income, survey season }\end{array}$ & Frequency of physical activity \\
\hline $\begin{array}{l}\text { Kim et al. } \\
\text { (2014) [22] }\end{array}$ & 10 & United States & $9-11$ & 61 & Greenness & $\begin{array}{l}\text { Radial } \\
\text { Network }\end{array}$ & $800 \mathrm{~m}$ & Home & $\begin{array}{l}\text { Age, sex, race, marital status, education, school, } \\
\text { grade, guardians, number of cars, country born, } \\
\text { environmental perceptions and satisfaction, } \\
\text { physical activity }\end{array}$ & Obesity \\
\hline
\end{tabular}


Table A2. Cont.

\begin{tabular}{|c|c|c|c|c|c|c|c|c|c|c|}
\hline \multirow{2}{*}{ Authors (Year) } & \multirow{2}{*}{$\begin{array}{c}\text { \# of } \\
\text { Analyses }\end{array}$} & \multicolumn{3}{|c|}{ Sample Characteristics } & \multirow{2}{*}{$\begin{array}{l}\text { Greenness } \\
\text { Type(s) }\end{array}$} & \multicolumn{3}{|c|}{ Buffer Characteristics } & \multirow{2}{*}{ Confound(s) } & \multirow{2}{*}{ Health Outcome(s) } \\
\hline & & Region(s) & Ages & Size & & Type & Size(s) & Center & & \\
\hline $\begin{array}{l}\text { Koohsari et al. } \\
\text { (2013) [56] }\end{array}$ & 4 & Australia & $18+$ & 320 & $\begin{array}{l}\text { Open } \\
\text { space }\end{array}$ & Network & $1 \mathrm{~km}$ & Home & $\begin{array}{c}\text { Age, sex, income, education, employment, } \\
\text { neighborhood quality, quality of nearby public } \\
\text { open spaces, presence of children less than } 12 \\
\text { years in the household, having a dog, residential } \\
\text { self-selection }\end{array}$ & Walking to/within open space \\
\hline $\begin{array}{l}\text { Laurent et al. } \\
\text { (2013) [57] }\end{array}$ & 3 & United States & Maternal age & 81,186 & Greenness & Radial & $\begin{array}{l}50 \mathrm{~m} \\
100 \mathrm{~m} \\
150 \mathrm{~m}\end{array}$ & Home & $\begin{array}{l}\text { Race, maternal age, poverty, insurance status, } \\
\text { parity, pyelonephritis }\end{array}$ & Preterm birth \\
\hline $\begin{array}{l}\text { Maas et al. } \\
(2008)[58]\end{array}$ & 2 & Netherland & $12+$ & 4899 & Greenspace & Radial & $\begin{array}{l}1 \mathrm{~km} \\
3 \mathrm{~km}\end{array}$ & Postal code & Age, sex, income, education, urbanicity & $\begin{array}{l}\text { Meet the public health } \\
\text { recommendations for physical activity }\end{array}$ \\
\hline $\begin{array}{l}\text { Maas et al. } \\
\text { (2009) [21] }\end{array}$ & 44 & Netherland & $12+$ & 345,143 & Greenspace & Radial & $\begin{array}{l}1 \mathrm{~km} \\
3 \mathrm{~km}\end{array}$ & Postal code & $\begin{array}{l}\text { Age, sex, education, urbanicity, employment, } \\
\text { healthcare insurance }\end{array}$ & $\begin{array}{c}\text { High blood pressure; Cardiac diseases } \\
\text { Coronary heart diseases; Stroke, brain } \\
\text { hemorrhage; Neck and back complaints; } \\
\text { Severe back complaints; Severe neck and } \\
\text { shoulder complaints; Severe elbow, wrist } \\
\text { and hand complaints; Osteoarthritis; } \\
\text { Arthritis; Upper respiratory tract } \\
\text { infection; Bronchi(oli)tis/pneumo nia; } \\
\text { Asthma, COPD; Migraine/severe } \\
\text { headache; Vertigo; Severe intestinal } \\
\text { complaints; Infectious disease of the } \\
\text { intestinal canal; MUPS; Chronic eczema; } \\
\text { Acute urinary tract infection; Diabetes } \\
\text { mellitus; Cancer; }\end{array}$ \\
\hline $\begin{array}{l}\text { Maas et al. } \\
\text { (2009) [59] }\end{array}$ & 6 & Netherland & $12+$ & 10,089 & Greenspace & Radial & $\begin{array}{l}1 \mathrm{~km} \\
3 \mathrm{~km}\end{array}$ & Postal code & $\begin{array}{l}\text { Age, sex, income, education, urbanicity, size of } \\
\text { household, social support }\end{array}$ & $\begin{array}{l}\text { General health; Number of health } \\
\text { complaints; Propensity for psychiatric } \\
\text { morbidity }\end{array}$ \\
\hline $\begin{array}{l}\text { Markevych } \\
\text { et al. (2014) [60] }\end{array}$ & 4 & Germany & Birth & 3203 & Greenness & Radial & $\begin{array}{l}100 \mathrm{~m} \\
250 \mathrm{~m} \\
500 \mathrm{~m} \\
800 \mathrm{~m}\end{array}$ & Home & $\begin{array}{l}\text { Sex, education, smoking, cohort, year of birth, } \\
\text { season of birth, maternal age }\end{array}$ & Birth weight \\
\hline $\begin{array}{l}\text { Markevych } \\
\text { et al. (2016) [61] }\end{array}$ & 12 & Germany & $10-15$ & 1552 & Greenness & Radial & $\begin{array}{l}100 \mathrm{~m} \\
300 \mathrm{~m} \\
500 \mathrm{~m}\end{array}$ & Home & $\begin{array}{l}\text { Age, sex, education, BMI, fasting status, physical } \\
\text { activity, puberty category, neighborhood SES, } \\
\text { study area }\end{array}$ & $\begin{array}{c}\text { Total cholesterol; Low density } \\
\text { lipoprotein; Triglyceride; High density } \\
\text { lipoprotein }\end{array}$ \\
\hline $\begin{array}{l}\text { Markevych } \\
\text { et al. (2016) [62] }\end{array}$ & 4 & Germany & 15 & 1192 & $\begin{array}{l}\text { Greenness } \\
\text { Tree } \\
\text { canopy }\end{array}$ & Radial & $500 \mathrm{~m}$ & Home & $\begin{array}{l}\text { Sex, education, BMI, cohort, accelerometer wear } \\
\text { year, season }\end{array}$ & MVPA \\
\hline $\begin{array}{l}\text { McMorris et al. } \\
\quad(2015)[3]\end{array}$ & 6 & Canada & $20+$ & 69,910 & Greenness & Radial & $500 \mathrm{~m}$ & Postal code & Age, sex, income, marital status, smoking & $\begin{array}{c}\text { Physical activity level; Participants in } \\
\text { leisure physical activity; Frequency of } \\
\text { physical activity; Physical activity index; } \\
\text { Monthly frequency of physical activity; } \\
\text { Energy expenditure }\end{array}$ \\
\hline $\begin{array}{l}\text { Mitchell et al. } \\
\text { (2016) [63] }\end{array}$ & 4 & Canada & 9-14 & 435 & Park & Radial & $\begin{array}{l}500 \mathrm{~m} \\
800 \mathrm{~m}\end{array}$ & Home & $\begin{array}{l}\text { Age, sex, frequent travel mode, siblings, } \\
\text { neighborhood SES }\end{array}$ & MVPA \\
\hline $\begin{array}{l}\text { Paquet et al. } \\
\text { (2013) [64] }\end{array}$ & 10 & Australia & $18+$ & 3751 & $\begin{array}{l}\text { Open } \\
\text { space }\end{array}$ & Network & $1 \mathrm{~km}$ & Home & Age, sex, income, education, neighborhood SES & $\begin{array}{l}\text { Cardiometabolic risk; Metabolic } \\
\text { equivalents (METs) }\end{array}$ \\
\hline
\end{tabular}


Table A2. Cont.

\begin{tabular}{|c|c|c|c|c|c|c|c|c|c|c|}
\hline \multirow{2}{*}{ Authors (Year) } & \multirow{2}{*}{$\begin{array}{c}\text { \# of } \\
\text { Analyses }\end{array}$} & \multicolumn{3}{|c|}{ Sample Characteristics } & \multirow{2}{*}{$\begin{array}{l}\text { Greenness } \\
\text { Type(s) }\end{array}$} & \multicolumn{3}{|c|}{ Buffer Characteristics } & \multirow{2}{*}{ Confound(s) } & \multirow{2}{*}{ Health Outcome(s) } \\
\hline & & Region(s) & Ages & Size & & Type & Size(s) & Center & & \\
\hline $\begin{array}{l}\text { Pereira et al. } \\
\text { (2012) [65] }\end{array}$ & 4 & Australia & $25+$ & 11,404 & Greenness & Network & $1.6 \mathrm{~km}$ & Home & $\begin{array}{l}\text { Age, sex, income, education, BMI, smoking, } \\
\text { healthcare card, non-gestational diabetes, } \\
\text { hypertension, high cholesterol, daily serves of } \\
\text { fruit and vegetables, risky drinking in the last } \\
\text { month, air quality }\end{array}$ & Coronary heart disease \\
\hline $\begin{array}{l}\text { Pereira et al. } \\
\text { (2013) [66] }\end{array}$ & 4 & Australia & $16+$ & 10,208 & Greenness & Network & $1.6 \mathrm{~km}$ & Home & $\begin{array}{l}\text { Age, sex, education, smoking, fruit and vegetable } \\
\text { intake }\end{array}$ & Overweight-or-obese; Obese \\
\hline $\begin{array}{l}\text { Picavet et al. } \\
\text { (2016) [14] }\end{array}$ & 22 & Netherland & $20-59$ & 4796 & Greenspace & Radial & $\begin{array}{l}125 \mathrm{~m} \\
1 \mathrm{~km}\end{array}$ & Home & Age, sex, education & $\begin{array}{l}\text { MVPA; Physical functioning; Pain; } \\
\text { General health; Vitality; BMI; Diabetes; } \\
\text { Cardio-vascular diseases; Asthma; } \\
\text { Chronic obstructive pulmonary diseases; } \\
\text { Systolic blood pressure; }\end{array}$ \\
\hline $\begin{array}{l}\text { Rundle et al. } \\
\text { (2013) [67] }\end{array}$ & 1 & United States & Adults & 13,102 & Park & Radial & $805 \mathrm{~m}$ & Home & Age, sex, race, education, neighborhood SES & BMI \\
\hline $\begin{array}{l}\text { Sallis et al. } \\
\text { (2016) [68] }\end{array}$ & 1 & $\begin{array}{l}\text { Belgium, Brazil, } \\
\text { Colombia, Czech } \\
\text { Republic, Denmark, } \\
\text { Hong Kong, } \\
\text { Mexico, New } \\
\text { Zealand, United } \\
\text { Kingdom, U.S. }\end{array}$ & $18-66$ & 6822 & Park & Network & $500 \mathrm{~m}$ & Home & $\begin{array}{l}\text { Age, sex, marital status, education, employment, } \\
\text { accelerometer wear time, neighborhood SES }\end{array}$ & MVPA \\
\hline $\begin{array}{l}\text { Salvo et al. } \\
\text { (2014) [31] }\end{array}$ & 2 & Mexico & $20-65$ & 677 & Park & Network & $\begin{array}{c}500 \mathrm{~m} \\
1 \mathrm{~km}\end{array}$ & Home & $\begin{array}{l}\text { Age, sex, marital status, education, BMI, } \\
\text { individual-level SES, vehicle ownership }\end{array}$ & MVPA \\
\hline $\begin{array}{l}\text { Schipperijn } \\
\text { et al. (2013) [69] }\end{array}$ & 6 & Denmark & $18-80$ & 1305 & Greenspace & Radial & $\begin{array}{l}100 \mathrm{~m} \\
300 \mathrm{~m} \\
600 \mathrm{~m} \\
1 \mathrm{~km} \\
2 \mathrm{~km} \\
3 \mathrm{~km}\end{array}$ & Home & Age, sex, education, general health & Participation in physical activity \\
\hline $\begin{array}{l}\text { Scott et al. } \\
(2007)[70]\end{array}$ & 1 & United States & $12-14$ & 1556 & Park & Radial & $805 \mathrm{~m}$ & Home & $\begin{array}{l}\text { Race, Neighborhood SES, number of accessible } \\
\text { schools and locked schools, presence of a school } \\
\text { within a half-mile, free/reduced price lunch at } \\
\text { a school level }\end{array}$ & METs \\
\hline $\begin{array}{l}\text { Sugiyama et al. } \\
\text { (2010) [71] }\end{array}$ & 2 & Australia & $18+$ & 1366 & $\begin{array}{l}\text { Open } \\
\text { space }\end{array}$ & Network & $1.6 \mathrm{~km}$ & Home & Age, sex, presence of children & Recreational walking \\
\hline $\begin{array}{l}\text { Thiering et al. } \\
\text { (2016) [72] }\end{array}$ & 2 & Germany & 15 & 837 & Greenness & Radial & $\begin{array}{l}500 \mathrm{~m} \\
1 \mathrm{~km}\end{array}$ & Home & $\begin{array}{l}\text { Age, income, education, BMI, smoking, physical } \\
\text { activity, puberty, cohort, study area }\end{array}$ & $\begin{array}{l}\text { Homeostatic model assessment of } \\
\text { insulin resistance }\end{array}$ \\
\hline $\begin{array}{l}\text { Thornton et al. } \\
\text { (2016) [12] }\end{array}$ & 3 & United States & $66+$ & 726 & Parks & Network & $1 \mathrm{~km}$ & Home & $\begin{array}{l}\text { Marital status, BMI, urbanity, smoking behavior, } \\
\text { employment status, age, sex, race, income, } \\
\text { education, residing in different regions, driver } \\
\text { license, health condition, caretaking duty, } \\
\text { self-rated mobility impairment, number of people } \\
\text { in household, , number of vehicles, years at current } \\
\text { address, neighborhood indicators (median age, } \\
\text { white, median household income) }\end{array}$ & $\begin{array}{l}\text { MVPA; Walking for errands; Walking for } \\
\text { leisure }\end{array}$ \\
\hline
\end{tabular}


Table A2. Cont.

\begin{tabular}{|c|c|c|c|c|c|c|c|c|c|c|}
\hline \multirow{2}{*}{ Authors (Year) } & \multirow{2}{*}{$\begin{array}{c}\text { \# of } \\
\text { Analyses }\end{array}$} & \multicolumn{3}{|c|}{ Sample Characteristics } & \multirow{2}{*}{$\begin{array}{l}\text { Greenness } \\
\text { Type(s) }\end{array}$} & \multicolumn{3}{|c|}{ Buffer Characteristics } & \multirow{2}{*}{ Confound(s) } & \multirow{2}{*}{ Health Outcome(s) } \\
\hline & & Region(s) & Ages & Size & & Type & Size(s) & Center & & \\
\hline $\begin{array}{l}\text { Ulmer et al. } \\
\text { (2016) [73] }\end{array}$ & 1 & United States & Under 65 & 4820 & $\begin{array}{l}\text { Tree } \\
\text { canopy }\end{array}$ & Radial & $250 \mathrm{~m}$ & Home & $\begin{array}{l}\text { Age, sex, race, income, marital status, education, } \\
\text { smoking, employment, English language ability, } \\
\text { time living at the current address, health } \\
\text { insurance, household size, food security status, } \\
\text { home ownership, poverty status, survey cycle }\end{array}$ & General health \\
\hline $\begin{array}{l}\text { Van den Berg } \\
\text { et al. (2010) [74] }\end{array}$ & 4 & Netherland & $19-97$ & 4529 & Greenspace & Radial & $\begin{array}{l}1 \mathrm{~km} \\
3 \mathrm{~km}\end{array}$ & Home & Age, sex, income, education, urbanicity & $\begin{array}{l}\text { Number of health complaints; General } \\
\text { health }\end{array}$ \\
\hline $\begin{array}{l}\text { Van Loon et al. } \\
\text { (2014) [75] }\end{array}$ & 4 & Canada & $8-11$ & 366 & Park & Network & $\begin{array}{l}200 \mathrm{~m} \\
400 \mathrm{~m} \\
800 \mathrm{~m} \\
1.6 \mathrm{~km}\end{array}$ & Home & Age, sex, race & MVPA \\
\hline $\begin{array}{l}\text { Wolch et al. } \\
\text { (2011) [20] }\end{array}$ & 1 & United States & $9-10$ & 3173 & Park & Radial & $500 \mathrm{~m}$ & Home & $\begin{array}{c}\text { Sex, race, cohort, AADT density, average urban } \\
\text { imperviousness, total length of arterial roads, } \\
\text { number of intersections, NDVI, percent below } \\
\text { poverty }\end{array}$ & BMI \\
\hline
\end{tabular}




\section{References}

1. James, P.; Banay, R.F.; Hart, J.E.; Laden, F. A review of the health benefits of greenness. Curr. Epidemiol. Rep. 2015, 2, 131-142. [CrossRef] [PubMed]

2. Blanck, H.M.; Allen, D.; Bashir, Z.; Gordon, N.; Goodman, A.; Merriam, D.; Rutt, C. Let's go to the park today: The role of parks in obesity prevention and improving the public's health. Child. Obes. 2012, 8, 423-428. [CrossRef] [PubMed]

3. McMorris, O.; Villeneuve, P.J.; Su, J.; Jerrett, M. Urban greenness and physical activity in a national survey of Canadians. Environ. Res. 2015, 137, 94-100. [CrossRef] [PubMed]

4. Dadvand, P.; Sunyer, J.; Basagaña, X.; Ballester, F.; Lertxundi, A.; Fernández-Somoano, A.; Estarlich, M.; García-Esteban, R.; Mendez, M.A.; Nieuwenhuijsen, M.J. Surrounding greenness and pregnancy outcomes in four Spanish birth cohorts. Environ. Health Perspect. 2012, 120, 1481-1487. [CrossRef] [PubMed]

5. Dadvand, P.; de Nazelle, A.; Figueras, F.; Basagaña, X.; Su, J.; Amoly, E.; Jerrett, M.; Vrijheid, M.; Sunyer, J.; Nieuwenhuijsen, M.J. Green space, health inequality and pregnancy. Environ. Int. 2012, 40, 110-115. [CrossRef] [PubMed]

6. Patterson, Z.; Farber, S. Potential path areas and activity spaces in application: A review. Trans. Rev. 2015, 35, 679-700. [CrossRef]

7. Cetin, M. Using GIS analysis to assess urban green space in terms of accessibility: Case study in Kutahya. Int. J. Sustain. Dev. World Ecol. 2015, 22, 420-424. [CrossRef]

8. Troped, P.J.; Wilson, J.S.; Matthews, C.E.; Cromley, E.K.; Melly, S.J. The Built Environment and Location-Based Physical Activity. Am. J. Perv. Med. 2010, 38, 429-438. [CrossRef] [PubMed]

9. Lachowycz, K.; Jones, A.P.; Page, A.S.; Wheeler, B.W.; Cooper, A.R. What can global positioning systems tell us about the contribution of different types of urban greenspace to children's physical activity? Health Place 2012, 18, 586-594. [CrossRef] [PubMed]

10. Jansen, M.; Ettema, D.; Pierik, F.; Dijst, M. Sports Facilities, Shopping centers or homes: What locations are important for adults' physical activity? A cross-sectional study. Int. J. Environ. Res. Public Health 2016, 13, 287. [CrossRef] [PubMed]

11. Burgoine, T.; Jones, A.P.; Brouwer, R.J.N.; Neelon, S.E.B. Associations between BMI and home, school and route environmental exposures estimated using GPS and GIS: Do we see evidence of selective daily mobility bias in children? Int. J. Health Geogr. 2015, 14, 8. [CrossRef] [PubMed]

12. Thornton, C.M.; Kerr, J.; Conway, T.L.; Saelens, B.E.; Sallis, J.F.; Ahn, D.K.; Frank, L.D.; Cain, K.L.; King, A.C. Physical activity in older adults: An ecological approach. Ann. Behav. Med. 2016, 51, 159-169. [CrossRef] [PubMed]

13. Cerin, E.; Mitáš, J.; Cain, K.L.; Conway, T.L.; Adams, M.A.; Schofield, G.; Sarmiento, O.L.; Reis, R.S.; Schipperijn, J.; Davey, R.; et al. Do associations between objectively-assessed physical activity and neighbourhood environment attributes vary by time of the day and day of the week? IPEN adult study. Int. J. Behav. Nutr. Phys. Act. 2017, 14, 34. [CrossRef] [PubMed]

14. Picavet, H.S.J.; Milder, I.; Kruize, H.; de Vries, S.; Hermans, T.; Wendel-Vos, W. Greener living environment healthier people? Exploring green space, physical activity and health in the Doetinchem Cohort Study. Prev. Med. 2016, 89, 7-14. [CrossRef] [PubMed]

15. Mother, D.; Liberati, A.; Tetzlaff, J.; Altman, D. Preferred reporting items for systematic reviews and meta-analyses: The PRISMA statement. PLoS Med. 2009, 6, e1000097.

16. Kuo, M. How might contact with nature promote human health? Promising mechanisms and a possible central pathway. Front. Psychol. 2015, 6, 1-8. [CrossRef] [PubMed]

17. McCurdy, L.E.; Winterbottom, K.E.; Mehta, S.S.; Roberts, J.R. Using nature and outdoor activity to improve children's health. Curr. Probl. Pediatr. Adolesc. Health Care 2010, 40, 102-117. [CrossRef] [PubMed]

18. Gascon, M.; Triguero-Mas, M.; Martínez, D.; Dadvand, P.; Forns, J.; Plasència, A.; Nieuwenhuijsen, M. Mental health benefits of long-term exposure to residential green and blue spaces: A systematic review. Int. J. Environ. Res. Public Health 2015, 12, 4354-4379. [CrossRef] [PubMed]

19. Lee, I.; Choi, H.; Bang, K.-S.; Kim, S.; Song, M.; Lee, B. Effects of forest therapy on depressive symptoms among adults: A systematic review. Int. J. Environ. Res. Public Health 2017, 14, 321. [CrossRef] [PubMed] 
20. Wolch, J.R.; Jerrett, M.; Reynolds, K.; McConnell, R.; Chang, R.; Dahmann, N.; Brady, K.; Gilliland, F.; Su, J.G.; Berhane, K. Childhood obesity and proximity to urban parks and recreational resources: A longitudinal cohort study. Health Place 2011, 17, 207-214. [CrossRef] [PubMed]

21. Maas, J.; Verheij, R.A.; de Vries, S.; Spreeuwenberg, P.; Schellevis, F.G.; Groenewegen, P.P. Morbidity is related to a green living environment. J. Epidemiol. Community Health 2009, 63, 967-973. [CrossRef] [PubMed]

22. Kim, J.-H.; Lee, C.; Olvera, N.E.; Ellis, C.D. The role of landscape spatial patterns on obesity in Hispanic children residing in inner-city neighborhoods. J. Phys. Act. Health 2014, 11, 1449-1457. [CrossRef] [PubMed]

23. Lee, A.C.K.; Maheswaran, R. The health benefits of urban green spaces: A review of the evidence. J. Public Health 2011, 33, 212-222. [CrossRef] [PubMed]

24. Keniger, L.; Gaston, K.; Irvine, K.; Fuller, R.A. What are the benefits of interacting with nature? Int. J. Environ. Res. Public Health 2013, 10, 913-935. [CrossRef] [PubMed]

25. Bowler, D.E.; Buyung-Ali, L.M.; Knight, T.M.; Pullin, A.S. A systematic review of evidence for the added benefits to health of exposure to natural environments. BMC Public Health 2010, 10, 456. [CrossRef] [PubMed]

26. Hodson, C.B.; Sander, H.A. Green urban landscapes and school-level academic performance. Landsc. Urban Plan 2017, 160, 16-27. [CrossRef]

27. Wu, C.-D.; McNeely, E.; Cedeño-Laurent, J.G.; Pan, W.-C.; Adamkiewicz, G.; Dominici, F.; Lung, S.-C.C.; $\mathrm{Su}$, H.-J.; Spengler, J.D. Linking student performance in Massachusetts elementary schools with the "greenness" of school surroundings using remote sensing. PLoS ONE 2014, 9, e108548. [CrossRef] [PubMed]

28. Kweon, B.-S.; Ellis, C.D.; Lee, J.; Jacobs, K. The link between school environments and student academic performance. Urban For. Urban Green. 2017, 23, 35-43. [CrossRef]

29. Lachowycz, K.; Jones, A.P. Greenspace and obesity: A systematic review of the evidence. Obes. Rev. 2011, 12, e183-e189. [CrossRef] [PubMed]

30. Bratman, G.N.; Hamilton, J.P.; Hahn, K.S.; Daily, G.C.; Gross, J.J. Nature experience reduces rumination and subgenual prefrontal cortex activation. Proc. Natl. Acad. Sci. USA 2015, 112, 8567-8572. [CrossRef] [PubMed]

31. Salvo, D.; Reis, R.S.; Stein, A.D.; Rivera, J.; Martorell, R.; Pratt, M. Characteristics of the built environment in relation to objectively measured physical activity among Mexican adults. Prev. Chronic Dis. 2014, 11, E147. [CrossRef] [PubMed]

32. Diez-Roux, A.V.; Mair, C. Neighborhoods and health. Ann. N. Y. Acad. Sci. 2010, 1186, 125-145. [CrossRef] [PubMed]

33. Perchoux, C.; Chaix, B.; Cummins, S.; Kestens, Y. Conceptualization and measurement of environmental exposure in epidemiology: Accounting for activity space related to daily mobility. Health Place 2013, 21, 86-93. [CrossRef] [PubMed]

34. Kwan, M.P. How GIS can help address the uncertain geographic context problem in social science research. Ann. GIS 2012, 18, 245-255. [CrossRef]

35. Kwan, M.P. The Uncertain Geographic Context Problem. Ann. Assoc. Am. Geogr. 2012, 102, $958-968$. [CrossRef]

36. Thierry, B.; Chaix, B.; Kestens, Y. Detecting activity locations from raw GPS data: A novel kernel-based algorithm. Int. J. Health Geogr. 2013, 12, 14. [CrossRef] [PubMed]

37. Hirsch, J.A.; Winters, M.; Clarke, P.; McKay, H. Generating GPS activity spaces that shed light upon the mobility habits of older adults: A descriptive analysis. Int. J. Health Geogr. 2014, 13, 51. [CrossRef] [PubMed]

38. Rodríguez, D.A.; Cho, G.-H.; Evenson, K.R.; Conway, T.L.; Cohen, D.; Ghosh-Dastidar, B.; Pickrel, J.L.; Veblen-Mortenson, S.; Lytle, L.A. Out and about: Association of the built environment with physical activity behaviors of adolescent females. Health Place 2012, 18, 55-62. [CrossRef] [PubMed]

39. Andrusaityte, S.; Grazuleviciene, R.; Kudzyte, J.; Bernotiene, A.; Dedele, A.; Nieuwenhuijsen, M.J. Associations between neighbourhood greenness and asthma in preschool children in Kaunas, Lithuania: A case-control study. BMJ Open 2016, 6, e010341. [CrossRef] [PubMed]

40. Astell-Burt, T.; Feng, X.; Kolt, G.S. Green space is associated with walking and moderate-to-vigorous physical activity (MVPA) in middle-to-older-aged adults: Findings from 203883 Australians in the 45 and up study. Br. J. Sports Med. 2014, 48, 404-406. [CrossRef] [PubMed]

41. Bijnens, E.; Zeegers, M.P.; Gielen, M.; Kicinski, M.; Hageman, G.J.; Pachen, D.; Derom, C.; Vlietinck, R.; Nawrot, T.S. Lower placental telomere length may be attributed to maternal residential traffic exposure; a twin study. Environ. Int. 2015, 79, 1-7. [CrossRef] [PubMed] 
42. Bodicoat, D.H.; O’Donovan, G.; Dalton, A.M.; Gray, L.J.; Yates, T.; Edwardson, C.; Hill, S.; Webb, D.R.; Khunti, K.; Davies, M.J.; et al. The association between neighbourhood greenspace and type 2 diabetes in a large cross-sectional study. BMJ Open 2014, 4, e006076. [CrossRef] [PubMed]

43. Chen, E.; Miller, G.E.; Shalowitz, M.U.; Story, R.E.; Levine, C.S.; Hayen, R.; Sbihi, H.; Brauer, M. Difficult family relationships, residential greenspace, and childhood asthma. Pediatrics 2017, 139, e20163056. [CrossRef] [PubMed]

44. Dadvand, P.; Villanueva, C.M.; Font-Ribera, L.; Martínez, D.; Basagaña, X.; Belmonte, J.; Vrijheid, M.; Grazuleviciene, R.; Kogevinas, M.; Nieuwenhuijsen, M.J. Risks and benefits of green spaces for children: A cross-sectional study of associations with sedentary behavior, obesity, asthma, and allergy. Environ. Health Perspect. 2014, 122, 1329-1335. [CrossRef] [PubMed]

45. Dadvand, P.; Wright, J.; Martínez, D.; Basagaña, X.; McEachan, R.R.C.; Cirach, M.; Gidlow, C.J.; de Hoogh, K.; Grazuleviciene, R.; Nieuwenhuijsen, M.J. Inequality, green spaces, and pregnant women: Roles of ethnicity and individual and neighbourhood socioeconomic status. Environ. Intern. 2014, 71, 101-108. [CrossRef] [PubMed]

46. Dadvand, P.; Sunyer, J.; Alvarez-Pedrerol, M.; Dalmau-Bueno, A.; Esnaola, M.; Gascon, M.; De Castro Pascual, M.; Basagaña, X.; Morgan, I.G.; Nieuwenhuijsen, M.J. Green spaces and spectacles use in schoolchildren in Barcelona. Environ. Res. 2017, 152, 256-262. [CrossRef] [PubMed]

47. Demoury, C.; Thierry, B.; Richard, H.; Sigler, B.; Kestens, Y.; Parent, M.-E. Residential greenness and risk of prostate cancer: A case-control study in Montreal, Canada. Environ. Int. 2017, 98, 129-136. [CrossRef] [PubMed]

48. Fuertes, E.; Markevych, I.; von Berg, A.; Bauer, C.-P.; Berdel, D.; Koletzko, S.; Sugiri, D.; Heinrich, J. Greenness and allergies: Evidence of differential associations in two areas in Germany. J. Epidemiol. Community Health 2014, 68, 787-790. [CrossRef] [PubMed]

49. Fuertes, E.; Markevych, I.; Bowatte, G.; Gruzieva, O.; Gehring, U.; Becker, A.; Berdel, D.; Berg, A.; Bergström, A.; Brauer, M.; et al. Residential greenness is differentially associated with childhood allergic rhinitis and aeroallergen sensitization in seven birth cohorts. Allergy 2016, 71, 1461-1471. [CrossRef] [PubMed]

50. Ghekiere, A.; Carver, A.; Veitch, J.; Salmon, J.; Deforche, B.; Timperio, A. Does parental accompaniment when walking or cycling moderate the association between physical neighbourhood environment and active transport among 10-12 year olds? J. Sci. Med. Sport 2016, 19, 149-153. [CrossRef] [PubMed]

51. Gómez, L.F.; Parra, D.C.; Buchner, D.; Brownson, R.C.; Sarmiento, O.L.; Pinzón, J.D.; Ardila, M.; Moreno, J.; Serrato, M.; Lobelo, F. Built environment attributes and walking patterns among the elderly population in Bogotá. Am. J. Prev. Med. 2010, 38, 592-599. [CrossRef] [PubMed]

52. Gong, Y.; Gallacher, J.; Palmer, S.; Fone, D. Neighbourhood green space, physical function and participation in physical activities among elderly men: The Caerphilly Prospective study. Int. J. Behav. Nutr. Phys. Act. 2014, 11, 40. [CrossRef] [PubMed]

53. Grazuleviciene, R.; Danileviciute, A.; Dedele, A.; Vencloviene, J.; Andrusaityte, S.; Uždanaviciute, I.; Nieuwenhuijsen, M.J. Surrounding greenness, proximity to city parks and pregnancy outcomes in Kaunas cohort study. Int. J. Hyg. Environ. Health 2015, 218, 358-365. [CrossRef] [PubMed]

54. James, P.; Hart, J.E.; Banay, R.F.; Laden, F. Exposure to greenness and mortality in a nationwide prospective cohort study of women. Environ. Health Perspect. 2016, 124, 1344-1352. [CrossRef] [PubMed]

55. Janssen, I.; Rosu, A. Undeveloped green space and free-time physical activity in 11 to 13-year-old children. Int. J. Behav. Nutr. Phys. Act. 2015, 12, 26. [CrossRef] [PubMed]

56. Koohsari, M.J.; Kaczynski, A.T.; Giles-Corti, B.; Karakiewicz, J.A. Effects of access to public open spaces on walking: Is proximity enough? Landsc. Urban Plan 2013, 117, 92-99. [CrossRef]

57. Laurent, O.; Wu, J.; Li, L.; Milesi, C. Green spaces and pregnancy outcomes in Southern California. Health Place 2013, 24, 190-195. [CrossRef] [PubMed]

58. Maas, J.; Verheij, R.A.; Spreeuwenberg, P.; Groenewegen, P.P. Physical activity as a possible mechanism behind the relationship between green space and health: A multilevel analysis. BMC Public Health 2008, 8 , 206. [CrossRef] [PubMed]

59. Maas, J.; van Dillen, S.M.E.; Verheij, R.A.; Groenewegen, P.P. Social contacts as a possible mechanism behind the relation between green space and health. Health Place 2009, 15, 586-595. [CrossRef] [PubMed] 
60. Markevych, I.; Fuertes, E.; Tiesler, C.M.T.; Birk, M.; Bauer, C.-P.; Koletzko, S.; von Berg, A.; Berdel, D.; Heinrich, J. Surrounding greenness and birth weight: Results from the GINIplus and LISAplus birth cohorts in Munich. Health Place 2014, 26, 39-46. [CrossRef] [PubMed]

61. Markevych, I.; Standl, M.; Sugiri, D.; Harris, C.; Maier, W.; Berdel, D.; Heinrich, J. Residential greenness and blood lipids in children: A longitudinal analysis in GINIplus and LISAplus. Environ. Res. 2016, 151, 168-173. [CrossRef] [PubMed]

62. Markevych, I.; Smith, M.P.; Jochner, S.; Standl, M.; Brüske, I.; von Berg, A.; Bauer, C.-P.; Fuks, K.; Koletzko, S.; Berdel, D.; et al. Neighbourhood and physical activity in German adolescents: GINIplus and LISAplus. Environ. Res. 2016, 147, 284-293. [CrossRef] [PubMed]

63. Mitchell, C.; Clark, A.; Gilliland, J. Built environment influences of children's physical activity: Examining differences by neighbourhood size and sex. Int. J. Environ. Res. Public Health 2016, 13, 130. [CrossRef] [PubMed]

64. Paquet, C.; Orschulok, T.P.; Coffee, N.T.; Howard, N.J.; Hugo, G.; Taylor, A.W.; Adams, R.J.; Daniel, M. Are accessibility and characteristics of public open spaces associated with a better cardiometabolic health? Landsc. Urban Plan 2013, 118, 70-78. [CrossRef]

65. Pereira, G.; Foster, S.; Martin, K.; Christian, H.; Boruff, B.J.; Knuiman, M.; Giles-Corti, B. The association between neighborhood greenness and cardiovascular disease: An observational study. BMC Public Health 2012, 12, 466. [CrossRef] [PubMed]

66. Pereira, G.; Christian, H.; Foster, S.; Boruff, B.J.; Bull, F.; Knuiman, M.; Giles-Corti, B. The association between neighborhood greenness and weight status: An observational study in Perth Western Australia. Environ. Health 2013, 12, 49. [CrossRef] [PubMed]

67. Rundle, A.; Quinn, J.; Lovasi, G.; Bader, M.D.M.; Yousefzadeh, P.; Weiss, C.; Neckerman, K. Associations between body mass index and park proximity, size, cleanliness, and recreational facilities. Am. J. Health Promot. 2013, 27, 262-269. [CrossRef] [PubMed]

68. Sallis, J.F.; Cerin, E.; Conway, T.L.; Adams, M.A.; Frank, L.D.; Pratt, M.; Salvo, D.; Schipperijn, J.; Smith, G.; Cain, K.L.; et al. Physical activity in relation to urban environments in 14 cities worldwide: A cross-sectional study. Lancet 2016, 387, 2207-2217. [CrossRef]

69. Schipperijn, J.; Bentsen, P.; Troelsen, J.; Toftager, M.; Stigsdotter, U.K. Associations between physical activity and characteristics of urban green space. Urban For. Urban Green. 2013, 12, 109-116. [CrossRef]

70. Scott, M.M.; Cohen, D.A.; Evenson, K.R.; Elder, J.; Catellier, D.; Ashwood, J.S.; Overton, A. Weekend schoolyard accessibility, physical activity, and obesity: The Trial of Activity in Adolescent Girls (TAAG) study. Prev. Med. 2007, 44, 398-403. [CrossRef] [PubMed]

71. Sugiyama, T.; Francis, J.; Middleton, N.J.; Owen, N.; Giles-Corti, B. Associations between recreational walking and attractiveness, size, and proximity of neighborhood open spaces. Am. J. Public Health 2010, 100, 1752-1754. [CrossRef] [PubMed]

72. Thiering, E.; Markevych, I.; Brüske, I.; Fuertes, E.; Kratzsch, J.; Sugiri, D.; Hoffmann, B.; von Berg, A.; Bauer, C.-P.; Koletzko, S.; et al. Associations of residential long-term air pollution exposures and satellite-derived greenness with insulin resistance in German adolescents. Environ. Health Perspect. 2016, 124, 1291-1298. [CrossRef] [PubMed]

73. Ulmer, J.M.; Wolf, K.L.; Backman, D.R.; Tretheway, R.L.; Blain, C.J.; O’Neil-Dunne, J.P.; Frank, L.D. Multiple health benefits of urban tree canopy: The mounting evidence for a green prescription. Health Place 2016, 42, 54-62. [CrossRef] [PubMed]

74. Van den Berg, A.E.; Maas, J.; Verheij, R.A.; Groenewegen, P.P. Green space as a buffer between stressful life events and health. Soc. Sci. Med. 2010, 70, 1203-1210. [CrossRef] [PubMed]

75. Van Loon, J.; Frank, L.D.; Nettlefold, L.; Naylor, P.-J. Youth physical activity and the neighbourhood environment: Examining correlates and the role of neighbourhood definition. Soc. Sci. Med. 2014, 104, 107-115. [CrossRef] [PubMed]

(c) 2017 by the authors. Licensee MDPI, Basel, Switzerland. This article is an open access article distributed under the terms and conditions of the Creative Commons Attribution (CC BY) license (http:/ / creativecommons.org/licenses/by/4.0/). 